\title{
PENGOLAHAN ECENG GONDOK (Eichhornia crassipes) UNTUK PENINGKATAN PENDAPATAN MASYARAKAT DAN PELESTARIAN DANAU BATUR DI DESA BUAHAN KECAMATAN KINTAMANI KABUPATEN BANGLI PROPINSI BALI
}

\author{
N.L.M. Pradnyawathi ${ }^{1}$ dan N.L. Kartini ${ }^{2}$
}

\begin{abstract}
ABSTRAK
Kegiatan Pengabdian masyarakat Pengolahan Eceng Gondok (Eichhornia crassipes) untuk Peningkatan Pendapatan Masyarakat dan Pelestarian Danau Batur, bertujuan : (1) meningkatkan kepedulian masyarakat akan kelestarian danau; (2) mengurangi cemaran melalui pengembangan pertanian ramah lingkungan; serta (3) mengurangi penyebaran enceng gondok melalui pengolahan enceng gondok menjadi produk yang bermanfaat seperti pupuk organic dan pakan ternak. Metode yang diterapkan dalam pemberdayaan masyarakat dengan kegiatan ini adalah sebagai berikut: (1) Kordinasi dan komunikasi dengan kelompok tani untuk merumuskan program mulai dari perencanaan, operasional dan evaluasi; (2) Penyuluhan untuk membangun persepsi dan pemahaman masyarakat mengenai inovasi atau program yang diterapkan; (3) Pelatihan mengenai terapan ipeks yang dialihkan bagi masyarakat; (4) Pendampingan yaitu pertemuan secara berkala dan berkelanjutan dengan kelompok tani hingga ipteks yang dialihkan dapat dilaksanakan secara mandiri. Teknologi yang akan digunakan untuk mengatasi permasalahan kelompok tani adalah teknologi fermentasi untuk pengolahan eceng gondok menjadi pupuk organik. Hasil yang didapat dari kegiatan pengabdian ini adalah kegiatan berlangsung dengan baik di mana kelompok tani Desa Buahan sangat antusias dengan kegiatan ini yang ditunjukkan dengan rata-rata kehadiran anggota kelompok petani adalah $63 \%$. Pupuk organic eceng gondok yang dihasilkan memenuhi syarat baku mutu kompos. Pemanfaatan eceng gondok yang merupakan gulma danau untuk pupuk organic di Desa Buahan, kecamatan Kintamani, Bangli akan sangat bermanfaat untuk peningkatan pendapatan petani disamping juga untuk menjaga kelestarian Danau Batur.
\end{abstract}

Kata kunci : KKNPPM, danau, eceng gondok, teknologi fermentasi, pupuk organic.

\begin{abstract}
Community Service for Water Hyacinth Processing (Eichhornia crassipes) for Increasing Community Revenue and Conservation of Lake Batur, aims to: (1) increase community awareness of lake sustainability; (2) reducing pollution through the development of environmentally friendly agriculture; and (3) reducing the spread of water hyacinth through processing water hyacinth into useful products such as organic fertilizers and animal feed. The methods applied in community empowerment with KKN PPM activities are as follows: (1) Coordination and communication with farmer groups to formulate programs starting from planning, operations and evaluation; (2) Counseling to build people's perceptions and understanding of the innovations or programs implemented; (3) Training on applied ipeks that are transferred to the community; (4) Mentoring, namely regular and continuous meetings with farmer groups to transfered science and technology can be carried out independently. The technology that be used to overcome the problems of farmer groups is fermentation technology for processing water hyacinth into organic fertilizer. The results obtained from this service activity were that the activity took place well where the Buahan Village farmer group was very enthusiastic about this activity, as indicated by the average attendance of the farmer group members was $63 \%$. Water hyacinth organic fertilizer produced meets compost quality standard requirements. The use of water hyacinth which is a lake weed for organic fertilizer in the village of Buahan, Kintamani sub-district,
\end{abstract}

\footnotetext{
${ }^{1}$ Program Studi Agroekoteknologi, Fakultas Pertanian, Universitas Udayana npradnyawathi@yahoo.com

${ }^{2}$ Program Studi Agroekoteknologi, Fakultas Pertanian, Universitas Udayana luhkartini@unud.ac.id
} 
Bangli will be very useful for increasing farmers' income as well as maintaining the preservation of Lake Batur.

Keywords: KKNPPM, lakes, water hyacinth, fermentation technology, organic fertilizer

\section{PENDAHULUAN}

Danau Batur berada di dalam kaldera gunung berapi aktif yaitu Gunung Batur yang berada di Kecamatan Kintamani Kabupaten Bangli. Danau ini terletak di ketinggian 1.031 m.dpl. Danau ini merupakan danau terluas di Bali dengan luas permukaan 15,9 km2. Rata-rata kedalaman danau $50,8 \mathrm{~m}$ dan kedalaman maksimal $88 \mathrm{~m}$. Air danau sebagian besar berasal dari air hujan yang tersaring melalui gunung. Kaldera Gunung Batur ini merupakan daerah pertanian yang penting. Air irigasi untuk pertanian ini akan mengalir kembali ke dalam danau setelah dipompa dengan membawa serta nutrisi dari daerah pertanian.
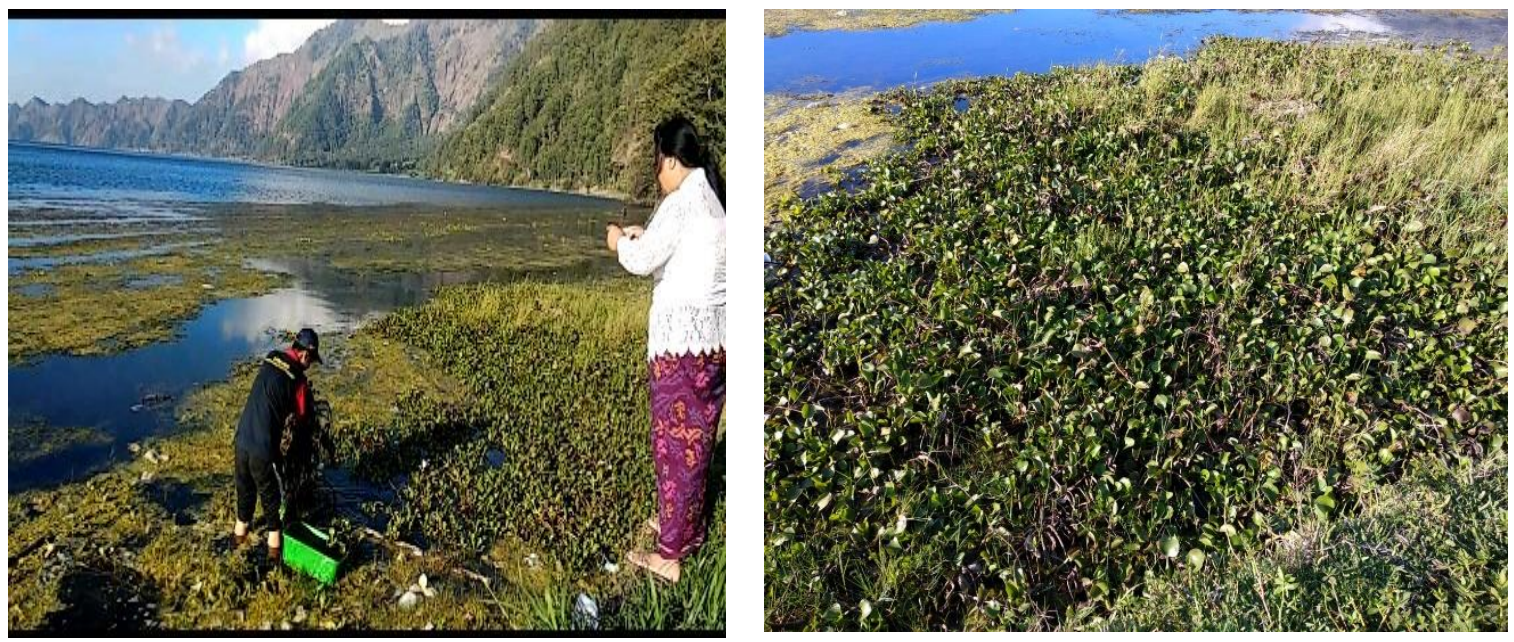

Gambar 1. Eceng gondok di Danau Batur

Danau Batur merupakan sumber untuk 1.200 mata air yang ada di Bali. Namun dewasa ini kondisi Danau Batur sangat memprihatinkan dan masuk dalam 15 danau kritis di Indonesia. Air danau tercemar dan mengalami pendangkalan (sidimentasi). Salah satu penyebab pendangkalan adalah pertumbuhan eceng gondok, yang merupakan salah satu persoalan yang dihadapi di Danau Batur. Dengan banyaknya eceng gondok yang tumbuh di danau menyebabkan air danau semakin cepat menguap dan tanaman eceng gondok yang mati akan turun ke dasar perairan sehingga mempercepat terjadinya proses pendangkalan.

Pertumbuhan enceng gondok berkaitan dengan aktivitas pertanian yang intensif yang dilakukan di sekitar danau. Pertanian sayuran yang memakai pupuk kimia sintetik terutama nitrogen dan super fosfat dengan dosis tinggi mendorong limbah senyawa tersebut ke dalam danau yang semakin tinggi pula. Kondisi tersebut menimbulkan gejala yang disebut eutrofikasi yang memicu tumbuhnya enceng gondok dan gulma lain serta menurunnya kualitas air danau.

Untuk mengatasi kondisi seperti dipaparkan di atas diperlukan solusi yang holistik untuk bisa menekan pertumbuhan populasi enceng gondok dan gulma lainnya di Danau Batur, baik secara preventif maupun untuk penanggulangan. Upaya preventif bisa dilakukan dengan mengurangi limbah nitrogen dan fospat dari aktivitas pertanian, sedangkan aksi penanggulangan dapat dilakukan dengan pengolahan enceng gondok menjadi pupuk organik. Pupuk organik hasil pengolahan enceng gondok dapat dijadikan sebagai sumber pupuk bagi pertanian sayuran di sekitar danau. Persoalan yang dihadapi adalah teknologi sistem pertanian yang ramah lingkungan dengan 
mengutamakan input organik serta teknik mengolah enceng gondok menjadi pupuk dan makanan ternak belum dikuasai oleh masyarakat di sekitar danau.

Berdasarkan pada hal-hal di atas maka kegiatan pengabdian masyarakat ini bertujuan untuk mengurangi penyebaran enceng gondok melalui pengolahan enceng gondok menjadi produk yang bermanfaat seperti pupuk organic dan pakan ternak.

\section{METODE PELAKSANAAN}

Metode yang diterapkan dalam pemberdayaan masyarakat dengan kegiatan KKN PPM ini adalah sebagai berikut: (1) Kordinasi dan komunikasi dengan kelompok tani untuk merumuskan program mulai dari perencanaan, operasional dan evaluasi; (2) Penyuluhan untuk membangun persepsi dan pemahaman masyarakat mengenai inovasi atau program yang diterapkan; (3) Pelatihan mengenai terapan ipeks yang dialihkan bagi masyarakat; (4) Pendampingan yaitu pertemuan secara berkala dan berkelanjutan dengan kelompok tani sehingga ipteks yang dialihkan dapat dilaksanakan secara mandiri oleh masyarakat. Kegiatan evaluasi dilakukan secara berkelanjutan terhadap kemajuan yang diperoleh.

Teknologi yang akan digunakan untuk mengatasi permasalahan kelompok sasaran adalah teknologi fermentasi untuk pengolahan eceng gondok menjadi pupuk organic.

\section{HASIL DAN PEMBAHASAN}

Kegiatan dilaksanakan mulai Tanggal 21 Juli 2018 sampai Tanggal 27 Agustus 2018. Teknologi yang didesiminasikan pada kelompok tani Desa Buahan adalah teknologi fermentasi pada pembuatan pupuk organic dari gulma danau eceng gondok dengan menggunakan fermentor Biomol. Komposisi dari Bio-mol yang dipakai adalah molasses yang telah mengandung hasil turunan EM4 yang dicampur dengan mikroorganisme local (MOL) dari limbah anggur terfortifikasi mineral alam Mg.

Pelaksanaan Kegiatan terdiri dari beberapa tahap yaitu : 1). Sosialisasi, 2). Persiapan materi, 3). Penyuluhan dan pelatihan singkat, 4). Pendampingan pembentukan demoplot pengolahan pupuk. Demoplot dilakukan di salah satu lahan petani yang telah disepakati bersama.

Sosialisasi, penyuluhan dan pelatihan singkat dilakukan di Wantilan Serba Guna Dusun Buahan, Desa Buahan pada tanggal 26 Juli 2018. Pembuatan demoplot dimulai dengan persiapan bahanbahan yaitu berupa : eceng gondok, serbuk gergaji, arang sekam, dolomit atau kapur Mg, fermentor (Bio-mol) dan air. Komposisi masing-masing bahan bisa dilihat pada Tabel 1. Penambahan serbuk gergaji dan arang sekam dimaksudkan untuk menambahkan unsur Karbon pada pupuk organik. Eceng gondok diambil dari danau dibawa dengan keranjang ke lokasi demoplot. Eceng gondok kemudian dicacah menjadi potongan-potongan kecil untuk mempercepat proses fermentasi. Cacahan eceng gondok kemudian ditambahkan dengan serbuk gergaji, arang sekam, dan dolomit, dicampur sampai merata. Campuran ini kemudian ditambahkan Bio-mol dan air. Selanjutnya campuran ditutup dengan terpal. Campuran ini perlu dibolakbalik setiap minggu. Dalam waktu 3 minggu pupuk organic eceng gondok sudah jadi dengan tanda bahan telah lapuk menyerupai tanah dan berwarna coklat kehitaman.

Tabel 1. Komposisi Bahan untuk membuat $500 \mathrm{~kg}$ Pupuk organic dari Eceng Gondok dengan Teknologi Fermentasi

\begin{tabular}{|l|l|l|}
\hline No & Bahan & Jumlah $\mathbf{K g})$ \\
\hline 1. & Eceng gondok & 400 \\
\hline 2. & Serbuk gergaji & 25 \\
\hline
\end{tabular}




\begin{tabular}{|l|l|l|}
\hline 3. & Arang sekam & 72,5 \\
\hline 4. & Dolomit & 2,5 \\
\hline & TOTAL BAHAN & $\mathbf{5 0 0}$ \\
\hline & & \\
\hline & Fermentor & Jumlah (liter) \\
\hline 1. & Bio-mol & 10 \\
\hline 2. & Air & 5 \\
\hline & TOTAL LARUTAN FERMENTOR & $\mathbf{1 5}$ \\
\hline
\end{tabular}

Pupuk organic eceng gondok hasil dari kegiatan demoplot kemudian dianalisis kandungan haranya di Laboratorium Ilmu Tanah Fakultas Pertanian Universitas Udayana. Hasil analisis menunjukkan bahwa kandungan hara untuk empat unsur utama yaitu C-organik, Nitrogen, P2O5 dan K2O memenuhi standar baku mutu kompos (Permentan, 2011). Hasil analisis dapat dilihat pada Tabel 2.

Tabel 2. Hasil Analisis Kandungan Hara Pupuk Organik Eceng Gondok dari Hasil Demoplot

\begin{tabular}{|l|l|l|l|l|}
\hline No & Komponen Hara & Kandungan & $\begin{array}{l}\text { Baku Mutu } \\
\text { Kompos }\end{array}$ & Keterangan \\
\hline 1. & C-organik & $31,15 \%$ & Minimal 15\% & Sesuai standar \\
\hline 2. & Hara makro (N+ P2O5+K2O) & $6,05 \% \%$ & Minimal 4\% & Sesuai standar \\
\hline
\end{tabular}

Kegiatan pembuatan pupuk organic dari eceng gondok ini berjalan dengan baik. Pada acara sosialisasi dan penyuluhan jumlah anggota kelompok tani yang hadir dari 30 anggota kelompok adalah 21 orang $(70 \%)$ Anggota kelompok sangat antusias mengikuti jalannya penyuluhan yang ditunjukkan dengan berbagai pertanyaan yang diajukan berkaitan dengan teknologi fermentasi ini. Kehadiran anggota kelompok tani pada pemeriksaan dan pembalikan pupuk organic minggu pertama adalah 16 orang $(53 \%)$. Kehadiran petani pada saat panen hasil pupuk organic adalah 20 orang $(67 \%)$. Rata-rata kehadiran anggota kelompok tani pada kegiatan pembuatan pupuk oganik dari eceng gondok ini adalah $63 \%$. Pada setiap pertemuan dihadiri juga oleh beberapa perangkat desa.

Pemanfaatan gulma danau eceng gondok untuk pembuatan pupuk organic dengan teknologi fermentasi akan sangat menguntungkan bagi petani dan masyarakat di sekitar danau. Dengan memproduksi sendiri pupuk organic tentu akan mengurangi pengeluaran petani untuk pembelian pupuk, di samping juga bisa mengurangi pemakain pupuk kimiawi. Petani juga bisa memproduksi pupuk organic untuk dijual sehingga bisa menambah pendapatan. Keuntungan lain yang diperoleh dari pemanfaatan gulma danau eceng gondok sebagai pupuk organic akan memberi kontribusi positif terhadap kelestarian Danau Batur melalui penerapan system pertanian ramah lingkungan karena akan mencegah residu bahan kimiawi yang hanyut ke danau dan mencegah terjadinya peristiwa eutrofikasi (Sardiana, et. al.,2014).

\section{KESIMPULAN DAN SARAN}

\subsection{Kesimpulan}

Hasil yang didapat dari kegiatan pengabdian ini adalah kegiatan berlangsung dengan baik di mana kelompok tani subak abian Desa Buahan sangat antusias dengan kegiatan ini yang ditunjukkan dengan rata-rata kehadiran petani $63 \%$. Pupuk organic eceng gondok yang dihasilkan memenuhi syarat baku mutu kompos untuk $\mathrm{C}$ organic dan unsur hara makronya. Pemanfaatan eceng gondok yang merupakan gulma danau untuk pupuk organic di Desa Buahan, kecamatan Kintamani, Bangli 
akan sangat bermanfaat untuk peningkatan pendapatan petani disamping juga untuk menjaga kelestarian Danau Batur.

\subsection{Saran}

Kegiatan pengabdian ini bisa berlanjut supaya bisa memberikan hasil yang maksimal seperti yang diharapkan

\section{UCAPAN TERIMA KASIH}

Penulis menyampaikan terima kasih yang sebesar-besarnya kepada Direktorat Jendral Penguatan Riset dan Pengembangan, Kementrian Riset, Teknologi dan Pendidikan Tinggi atas bantuan dana melalui program KKN PPM sehingga kegiatan KKN PPM di Desa Buahan, Kecamatan Kintamani, Kabupaten Bangli dapat terlaksana dengan baik.

\section{DAFTAR PUSTAKA}

Dudal, R., and R.N Roy. 1995. Integrated Plant Nutrition Systems. FAO Fertilizer and Plant Nutrition Bulletin No. 12. FAO, Rome.

Dwijoseputro. 1990. Dasar-dasar Mikrobiologi. Jambatan.

Pelczar dan Chan. 1986. Dasar-dasar Mikrobiologi 1 Universitas Indonesia. (UI-Press) Jakarta..

Peraturan Menteri Pertanian Nomor 70/Permentan/SR.140/2011 tentang Pupuk Organik, Pupuk Hayati dan Pembenah tanah.

Sardiana, I.K., I.M. Adnyana, I.B.P. Manuaba and I.G.A.M S Agung. 2014. Soil Organic Carbon, Labile Carbon and Organic Carbon Storage under Organic and Conventional Systems of Chinese Cabbage in Baturiti, Bali Indonesia. Journal of Biology, Agriculture and Healthcare. Vol. 4. No. 21. Pp. 63-71

Sutanto, R. 2000. Tantangan Global dalam Menghadapi Kerawanan Pangan dan Pengetahuan Tradisional dalam Pembangunan Pertanian. 